\title{
TREATING PKS CANDIDAT ANALYZE IN SUNGAI PENUH TOWN
}

\author{
Izendrizal
}

\begin{abstract}
This research was aimed to find out how to treat PKS candidates and to analyze the influences of the loyality of PKS candidates in Sungai Penuh town. The population was all the candidats that contained 46 people. This research was qualitative. It was because its goals to describe the things are. The technique of collecting data was descritive analysis. The results of this research were: 1. The ideologi of the treatment was based on the Al-qur'an and Al-hadits. 2. The treatment aimed at treating people apply islamic roles in daily life. 3. The way to treat was Halaqo/Liqo.
\end{abstract}

\section{Keywords: Treating PKS Candidats}

\section{PENDAHULUAN}

\section{Latar Belakang}

Partai Keadilan Sejahtera (PKS)

merupakan salah satu partai politik Indonesia yang mampu mempertahankan perolehan suara dari satu Pemilu ke Pemilu berikutnya. Ketika Partai-Partai besar seperi Golkar, PDIP dan PPP terus mengalami penurunan jumlah perolehan suara dari satu Pemilu ke Pemilu berikutnya, bahkan tingkat electoral volatility partai-partai tersebut cukup tinggi, maka tidak demikian halnya dengan PKS, perolehan suara PKS mengalami kenaikan dari satu Pemilu ke Pemilu berikutnya.

Menjelang Pemilihan Umum tahun 2014 Partai Keadilan Sejahtera, diterpa dengan persoalan yang sangat serius dimana Presiden Partai Keadilan Sejahtera ditangkap oleh Komisi Pemberantasan Korupsi. Alasan penangkapan diduga Ia menerima hadiah atau janji dari Maria Elisabed Liman selaku direktur utama PT. Indoguna Utama. Hadiah atau janji tersebut diberikan untuk mempengaruhi pejabat di Kementerian Pertanian terkait izin penambahan kuota impor daging sapi PT. Indoguna Utama. Selain
Presiden Partai Keadilan Sejahtera petinggi Partai Keadilan Sejahtera yang lain juga diduga oleh Komisi Pemberantasan Korupsi ikut berperan dalam kasus ini adalah Ketua Majelis syuro Partai Keadilan Sejahtera. Banyak kalangan memprediksi pada pemilu 2014 PKS akan di tinggalkan oleh para pemilihnya karena adanya kasus Luthfi Hasan Ishaaq. Pada pemilu 2014 terjadi hal yang sebaliknya dari prediksi banyak kalangan. Perolehan suara nasional PKS secara elektoral naik dari 8.204.946 suara pada tahun 2009 menjadi 8.480.204 suara pada pemilu 2014. Keberhasilan PKS dalam mempertahankan jumlah perolehan suara juga terjadi di beberapa daerah termasuk di Kota Sungai Penuh. Pada Pemilu 2009 PKS hanya memperoleh 1 kursi di DPRD sedangkan pada pemilu 2014 PKS berhasil mendudukkan 2 wakilnya di DPRD Kota Sungai Penuh. Keberhasilan ini tentunya tidak terlepas dari loyalitas dan militansi kader-kader PKS yang dibangun melalui tarbiyah.

Menurut penulis ada beberapa faktor yang membuat pemilih PKS tetap loyal di Kota Sungai Penuh. Pertama, adanya pertemuan rutin sekali dalam seminggu yang dalam bahasa internal PKS disebut liqo pekanan. 
Dalam pertemuan ini dilakukan pengajian al-qur'an, taujih atau nasehat dari kader senior kepada kaader-kader yang hadir dalam pertemuan tersebut kemudian juga disampaikan perkembangan dahwah secara nasional dan lokal serta hal-hal yang berkembang termasuk jika ada instruksi dari Dewan Pimpinan Pusat PKS. Apabila ada berita-berita yang bisa berdampak pada citra Partai maka dalam pertemuan tersebut dilakukan klarifikasi kepada kader-kade. Para kader dianjurkan juga untuk menyampaikan klarifikasi ini kepada masyarakat luas.

Kedua, jelas dan teraturnya garis komando dalam struktur Partai adalah hal yang sangat penting dalam mengendalikan situasi internal Partai yang nantinya tentu akan berpengaruh kepada eksternal Partai atau masyarakat. Ketika ada prahara politik yang menimpa PKS seperti tertangkapnya Presiden PKS Luthfi Hasan Ishaaq oleh KPK, DPP dan Majelis Syuro PKS bisa cepat bertindak untuk merespon situasi politik untuk menyelamatkan citra, keutuhan dan masa depan Partai dengan mengganti Presiden Partai serta menyatakan bahwa apa yang menimpa Luthfi Hasan Ishaaq adalah sebuah konspirasi besar yang ingin menghancurkan PKS, seruan ini disampai melalui struktur Partai dari Dewan Pimpinan Pusat ke Dewan Pimpinan Wilayah ke Dewan Pimpinan Daerah dan hal ini diyakini dan dipatuhi oleh semua kader PKS. Kondisi internal PKS betul-betul solid bahkan meningkatkan militansi kader karena ada rasa didzalimi sehingga menimbulkan rasa solidaritas yang tinggi.

Ketiga, pasca pergantian pimpinan, Anis Mata Presiden PKS yang baru sangat intens melakukan komunikasi dan konsolidasi internal
Partai dengan melakukan "tour politik" ke daerah-daerah untuk memberikan klarifikasi persoalan yang sedang menimpa mantan Presiden PKS Luthfi Hasan Ishaaq serta memberikan semangat kepada para kader di daerah. Dua hari pasca pelantikan sebagai Presiden PKS Anis matta lansung turun ke daerah, Jawa Barat wilayah pertama yang dia kunjungi kemudian, Yogyakarta, Surabaya, Makassar, Jawa Tengah dan Sumatera Utara. Dalam kunjungannya Anis Matta memberikan orasi politik : "Saya menyampaikan salam cinta dari ketua Majelis syuro KH. Hilmi Aminuddin kepada antum semua. Selain itu ada pula salam cinta dari ustadz Luthfi Hasan Ishaaq dan kita percaya pada integritasnya apa yang menimpanya adalah sebuah konspirasi besar untuk menghancurkan Partai. Kita yakin bahwa musibah ini adalah sebuah isyarat dari Allah SWT bahwa kita akan naik kelas. Ikhwah sekalian berpikirlah dengan cara yang tidak dipikirkan oleh lawan-lawan kita. Jangan membiarkan kalimat-kalimat para pengamat membentuk cara berpikir kita tapi berpikirlah dengan cara yang tidak dipikirkan oleh para pengamat itu. Ada pelajaran penting bagi setiap kader dakwah, bahwa sebesar apapun goncangan badai, ombak dan turbulensi yang dihadapi, maka satu-satunya hal yang tidak boleh dilakukan adalah berhenti berjalan. Dalam situasi yang sesulit apapun, para kader harus terus bekerja dan bekerja dengan cara yang progresif. Insya Allah kemenangan akan sesuai dengan takdir Allah SWT di Pemilu 2014 yang akan datang". Hal ini disampaikan berulangulang di setiap ada acara temu kader tentu hal ini seperti sebuah doktrin politik yang tertanam kuat dipikiran para kader bahkan merasuk kedalam alam bawah sadar. Apa yang dilakukan oleh Dewan Pimpinan Pusat Partai 
Keadilan Sejahtera dibawah pimpinan Anis matta sangat efektif menjaga loyalitas kader terhadap Partai.

Dari uraian tersebut peneliti tertarik untuk melakukan penelitian lebih lanjut dengan judul ANALISIS

\section{PEMBINAAN KADER PKS DI} KOTA SUNGAI PENUH.

\section{Perumusan Masalah}

Berdasarkan uraian latar belakang masalah diatas dan mencermati pengalaman dinamika partai politik di Indonesia khususnya di Kota Sungai Penuh maka, diperlukan pengkajian dan penelitian bagaimana proses tarbiyah di dalam PKS sehingga mampu menjaga kadernya tetap loyal dan tetap bisa menempatkan kadernya di DPRD Kota Sungai Penuh. Berangkat dari hal tersebut maka, penulis ingin merumuskan masalah yang akan dikaji melalui suatu penelitian dengan melihat persoalan pada:

"Bagaimana proses pembinaan kader PKS di Kota Sungai Penuh ?" penelitian ini akan menjelaskan mengapa kader PKS tetap loyal dan tetap bekerja pasca pimpinannya terjerat kasus korupsi.

\section{Tujuan dan Manfaat Penelitian Tujuan Penelitian}

Secara ringkas tujuan yang ingin dicapai dari penelitian ini adalah sebagai berikut :

1. Untuk mengetahui bagaimana proses pembinaan kader PKS di Kota Sungai Penuh

2. Untuk menganalisis pengaruh pembinaan terhadap loyalitas kader PKS Kota Sungai Penuh

\section{Manfaat Penelitian}

Manfaat yang diharapkan akan dapat diperoleh dengan melakukan penelitian ini, antara lain:
1. Bagi penulis, penelitian ini bermanfaat untuk mengasah kemampuan penulis dalam meneliti fenomena psikologis massa Partai, sehingga menambah pengetahuan penulis mengenai masalah yang diteliti

2. Secara teoritis hasil peneltian ini sekiranya dapat bermanfaat menambah khazanah ilmu dalam menganalisis kesetiaan kader/ pemilih

3. Menemukan solusi dan strategi pemecahan masalah yang di hadapi

\section{Landasan Teori \\ Analisis}

Dalam Kamus Besar Bahasa Indonesia Analisis di definisikan sebagai penyelidikan terhadap suatu peristiwa (karangan, perbuatan, dan sebagainya) untuk mengetahui keadaan yang sebenarnya (sebab-musabab, duduk perkara, dan sebagainya). Sementara itu Wiradi (www.gurupendidikan.com/pengertian analisis-menurut-para-ahli)

mendefinisikan analisis sebagai sebuah aktivitas yang memuat kegiatan memilah, mengurai, membedakan sesuatu untuk digolongkan menurut kriteria tertentu lalu di cari di taksir makna dan kaitannya.

Fungsi analisis

a. Untuk mengidentifikasi ciri-ciri permasalahan yang dihadapi, sehingga nantinya dapat diketahui langkah-langkah penyelesaian secara tepat dan sesuai

b. Untuk memberikan spesifikasi atau keterangan terperinci mengenai objek permasalahan. Hal ini tentu mendukung proses penemuan solusi dari permasalahan yang di analisis 
c. Memberikan gambaran dasar mengenai kesimpulan dan strategi yang akan dilakukan.

\section{Pengertian Tarbiyah}

Tarbiyah menurut bahasa adalah pendidikan. Secara umum, tarbiyah dapat dikembalikan kepada tiga kata kerja yang berbeda,yakni Rabaa-yarbuu yang bermakna namaa-yanmuu, artinyaberkembang. Rabiya-yarbaa yang bermakna nasya-a, tara'raa,artinya tumbuh. Rabba-yarubbu yg bermakna aslahahu, tawallaaamrahu, sasa-ahuu, wa qaama 'alaihi, wa ra'aahu, yang artinyamasing-masing adalah memperbaiki, mengurus, memimpin, menjaga dan memeliharanya (atau mendidik).

Sedangkan menurut istilah tarbiyah adalah prosespengembangan dan bimbingan, meliputi jasad, akal, dan jiwa, yang dilakukan secara berkelanjutan, dengan tujuan akhir si anak didiktumbuh dewasa dan hidup mandiri di tengah masyarakat kegiatan yang disertai dengan penuh kasih sayang, kelembutan hati, perhatian, bijak,dan menyenangkan (tidak membosankan).

Tarbiyah memiliki arti pembinaan atau pendidikan berbasis kelompok kecil di bawah bimbingan seorang murabbi yang dilakukansebagai kegiatan non formal partai yang merupakan posisi kunci bagi pengkaderan PKS. Tarbiyah merupakan kegiatan inti dari proses kaderisasi PKS. Keberhasilan Tarbiyah yang dilakukan oleh murabbi akan menghasilkan kader yang sangat solid terhadap partai.

Murabbi memiliki binaan sesuai dengan tingkatnya. Pada tahap pemula, binaan merupakan simpatisan yang belum begitu banyak tahu mengenai substansi kegiatan kaderisasi yang dilakukan. Pada tahap ini, binaan hanya mengetahui bahwa murabbi adalah seorang Pembina Tarbiyah yang mengajarkan agama kepada dirinya.

Berbeda dengan binaan tahap menengah. Binaan sudah mulai mengetahui lebih dalam hakekat sebenarnya kegiatan Tarbiyah. Selain dia menjadi binaan, ia juga akan memiliki binaan beberapa orang sehingga otomatis akan menjadi murabbi bagi binaan yang akan didapat.

Tahap selanjutnya yaitu binaan tingkat atas. Tahap ini binaan telah memahami dengan baik mengenai kaderisasi yang dilakukan. Pada tingtkat ini, binaan sudah bukan semata-mata menjadi simpatisan tetapi sudah menjadi kader secara formal dengan mengikuti tahaptahap yang dilakukan oleh kepartaian. Pada tahap ini binaan juga diwajibkan memiliki anggota binaan yang akan dipersiapkan untuk melanjutkan misi Tarbiyah.

Tujuan Tarbiyah :

Secara umum Tarbiyah bertujuan membentuk manusia yang hanya beribadah kepada Allah SWT dan memakmurkan bumi hanya dengan aturan- aturan Allah baik yang berupa wahyu atau pun sunatullah, sehingga lahir suasana kehidupan yang Islami di bumi ini. Dalam rangka mewujudkan hal tersebut dijabarkan dalam tiga tujuan utama dari Tarbiyah islamiyah, yaitu:

1). Terbentuknya Tashawur (persepsi) Islami yang jelas. Islam sebagai din, sebagai pedoman hidup dari Allah SWT mencakup seluruh aspek kehidupan dan perilaku untuk seluruh zaman dan ummat manusia. Ketidakmenyeluruhan persepsi terhadap Islam akan mengakibatkan Islam terisolasi dari pentas kehidupan, juga menjadi sumber bid'ah, khurafat, takhayul, dantradisi jahiliyah serta berbagai 
kontradiksi. Bahaya persepsi yang parsial (Juz'I) dijelaskan dalam firman Allah Q.S. Al Baqarah:85 sedangkan kejelasan dan keuniversalan Islam terlihat pada firman Allah Q.S. AnNisaa':89.

2). Membentuk Syakhsiyah Islamiyah (pribadi yang Islami) Pribadi yang Islami adalah pribadi yang menjadikan nilainilai Islam sebagai bahan utama pembentuk kepribadiannya, sehingga identitas dirinya benarbenar mencerminkan keislamannya. Komponen dasar bagi terbentuknya kepribadian seseorang adalah keyakinan, pendirian, perasaan, pemikiran, watak, performa, dan perilaku. Akidah Islamiyah adalah dasar pembentukan dari semua komponen tersebut. Tarbiyah diharapkan menghasilkan buah yang baik. Buah yang diharapkan dari pembinaan Islami (tarbiyah islamiyah) adalah terciptanya sosok pribadi muslim yang ideal, pribadi muslim yang kaffah. Yaitu pribadi muslim yang mengimplemetasikan nilai-nilai Islam secara keseluruhan, tidak hanya bagian per bagian.

Tujuan yang diharapkan setelah peserta mengikuti proses tarbiyah adalah :

1) Memiliki aqidah yang lurus dan kuat

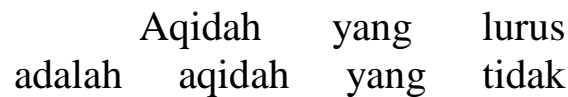
menyimpang dari aqidah ahlussunnah wal jamaah, aqidah yang kuat adalah aqidah yang tertanam dengan kuat di dalam hati yang nampak pada amalan, bukan aqidah yang sekedar teori dan pemahaman belaka.
2). Memahami Islam dengan pemahaman yang benar dan sempurna.

Pemahaman yang benar adalah pemahaman yang bersumber dari Qur'an dan Sunnah menurut paham salafush shaleh. Pemahaman yang sempurna adalah dengan mempelajari Islam secara sempurna (tidak parsial) karena pemahaman yang parsial akan melahirkan ketersesatan. Firqahfirqah yang sesat lahir karena pemahaman yang parsial terhadap Islam, Khawarij hanya mengambil nash-nash ancaman dan mengabaikan nash-nash rahmat dan ampunan, Murjiah hanya mengambil nashnash rahmat dan ampunan lalu mengabaikan nash-nash ancaman, Islam Liberal hanya mengambil beberapa kaidahkaidah umum lalu mengabaikan begitu banyak nash-nash yang sifatnya khusus.

3). Menghidupkan adab-adab Islam keseharian seperti adab makan dan minum, adab tidur, adab buang air, adab naik kendaraan, adab berpakaian dan lain-lain.

4). Menghiasi diri dengan akhlak yang mulia seperti sifat amanah, tawadhu, berani, jujur dan lainlain.

\section{Loyalitas Kader}

Loyalitas merupakan sikap yang setia pada sesuatu tanpa paksaan atau tekanan dari pihak manapun. Sikap ini lahir dari keyakinan dan kesadran yang terbentuk dari hasil sosialisasi dengan lingkungan sekitar. Kader adalah sekelompok orang yang terorganisir secara terus-menerus dan menjadi tulang punggung bagi keastuan yang lebih besar, (Rohmadi, 2008) 
Loyalitas kader merupakan realitas sosial politik yang tidak terlepas dari pengaruh faktor eksternal dan internal. Secara eksternal merupakan hasil dari sosialisasi nilai-nilai dari lingkungannya, sedangkan secara internal merupakan tindakan yang didasarkan atas rasionalitas berdasarkan pengetahuan dan pengalaman yang dimiliki. Sehingga kader partai dan partisipasi politik merupakan dua hal yang tidak dapat dipisahkan. Partisipasi politik dapat terwujud dalam berbagai bentuk. Menurut Samuel P. Hutington dan Joan Nelson (1990) salah satu wujud dari partsipasi politik ialah kegiatan pemilihan yang mencakup suara, sumbangansumbangan untuk kampanye, bekerja dalam suatu pemilihan, mencari dukungan bagi seorang calon atau setiap tindakan yang bertujuan untuk mempengaruhi hasil proses pemilihan.

Kefiguran puncak partai, akan sangat menentukan loyalitas pemilih tradisional, selain kerja-kerja ekstra para caleg (DPR/DPRD) dengan tampil maksimal dihadapan pemilih pada saat kampanye. Elite-elite lama akan segera tergeser dengan kehadiran elite baru dengan partai baru -yang barangkali jauh lebih "menjanjikan" daripada elite lama yang cenderung mempertahankan status-quo. Dalam sistem politik yang mapan seperti Indonesia, loyalitas pemilih terhadap partai ditentukan oleh kondisi-kondisi sosio-politik yang dihadapi, selalu mengambang dan menyebar. Pemilu 1999, PDIP menang, pemilu 2004 Golkar yang menang, dan pemilu 2009 Demokrat yang menang, itu berarti loyalitas pemilih selalu mengikuti kecendrungan perubahan.

\section{Ruku Bai'at dalam Gerakan PKS}

Rukun bai'at disebut juga janji setia anggota kepada gerakan PKS. Rukun ini sebenarnya dibuat oleh Hasan Al-Banna sebagai janji setia setiap anggota gerakan Ikhwanul Muslimin. Ada sepuluh rukun bai'at: fahm (Pemahaman), ikhlas, amal, jihad, tadhiyyah (pengorbanan), taat (ketaatan), tsabat (keteguhan), tajjarud (kemurnian), ukhwah (persaudaraan), dan tsiqoh (kepercayaan). Sebagai manifestasi dari pemahaman islam yang kaffah, rukun baiat merupakan syarat utama bagi kader dalam gerakan tarbiyah/PKS. Lebih jauh rukun baiat menurut Hasan Al-Banna merupakan sebuah keniscayaan dan harus dipenuhi oleh setiap kader gerakan agar dapat menununaikan tugasnya dalam jamaah (gerakan), dan tidak terpenuhinya salah satu rukun ini akan membuat seorang kader menjadi cacat, dan selanjutnya cacat pula gerakan oleh kader tersebut (Sa'id Hawwa, 2000).

Rukun bai'at menjadi keharusan bagi gerakan PKS untuk disampaikan kepada kadernya. Rukun bai'at disampaikan pada halaqoh/Liqo dan secara khusus ada penugasan dari murabbi kepada binaannya untuk membaca dan menghapal rukun bai'at ini. Menurut sa'id Hawwa, tanggungjawab pertama gerakan adalah mewujudkan rukun-rukun bai'at yang sepuluh kepada setiap individu, sebagai jalan untuk membangun gerakan islam yang komprehensif (kaffah).

\section{Halaqoh / Liqo}

Gerakan tarbiyah tumbuh sekitar tahun 1980-an yang mengambil basis gerakannya di masjid-masjid universitas yang tersebar di Indonesia. Salah seorang pelopor gerakan tarbiyah di kampus yang merupakan tokoh dari DDII adalah Ir. Imaduddin Abdul Rahim yang memprakarsai pola pengkaderan model Ikhwanul Muslimin yang dikenal dengan "usrah" atau halaqoh/Liqo'at. Program halaqoh/liqo ini berawal di masjid Salman Institut Teknologi Bandung (ITB) yang kemudian menyebar ke Universitas 
sekuler lainnya seperti: UI, IPB, UGM, UNDIP, USU dan lain-lain. Halaqoh/liqo ini di bimbing oleh seorang murabbi/guru biasanya seorang kader senior atau alumni dari perguruan tinggi dari Timur Tengah yang dihormati dan ditaati kader yang ikut dalam halaqoh/liqo tersebut. Adapun materi liqo sudah disusun secara Nasional oleh DPP PKS. Materi liqo terdiri dari pertama, ta'ruf/perkenalan, dimaksudkan agar setiap anggota/kader saling mengenal sehingga memudahkan untuk kontak dan komunkasi jika suatu saat ada tugas dari partai. Kedua, tilawah dan mentadaburi al-qur'an, setiap kader membaca ayat-ayat suci alqu'an kemudian diikuti dengan penyampaian tafsir oleh salahsatu kader yang telah ditunjuk oleh murabbi tujuannya adalah agar kader meresapi dan membangun pola pikir qur'ani. Ketiga, Infaq tujuannya adalah melatih kepekaan sosial kader terhadap sesama dan lingkungan. Hasil infaq tadi digunakan untuk meringankan beban kader atau orang-orang dilingkungannya jika di timpa musibah misalnya, sakit atau kematian. Keempat, tausiyah atau materi pokok dalam liqo yang disampaikan oleh murabbi/guru, yang disampaikan pada intinya adalah bagaimana menjadi muslim yang kappah dikatakan muslim yang kappah adalah seorang muslim yang tidak mendikotomi kerja dunia dan akhirat. Semua kegiatan yang kita lakukan apapun itu adalah ibadah kepada Allah SWT termasuk berpolitik jadi politik bukanlah urusan duniawi tapi juga bentuk ibadah kepada Allah. Karena salahsatu tugas manusia sebagai khalifah di muka bumi adalah menegakkan hukum Allah azza wajjala, menegakkan hukum lebih efektif jika kita memegang kekuasaan. Setelah itu disampaikan mengenai perkembangan dakwah secara nasional dan lokal serta hal-hal yang dianggap perlu.

\section{Gaya Kepemimpinan}

Gaya kepemimpinan adalah norma prilaku yang digunakan seseorang pada saat orang tersebut mencoba mempengaruhi prilaku orang lain seperti yang dia lihat (Thoha Mithfah, 1988). Sementara itu Flippo mengatakan bahwa gaya kepemimpinan dirumuskan sebagai pola prilaku yang dirancang untuk memadukan kepentingan organisasi dan personalia guna mengejar beberapa sasaran (Flippo, 1982).

Menurut studi kepemimpinan Universitas Iowa, Ronald Lippit dan Ralph K. White (Sutarto, 1989) disebutkan ada tiga gaya kepemimpinan yaitu:

1. Gaya kepemimpinan otoriter atau diktator, kepemimpinan gaya otoriter antara lain berciri:

a. Wewenang mutlak terpusat pada pimpinan

b. Keputusan selalu dibuat oleh pimpinan

c. Komunikasi berlansung satu arah dari pimpinan kepada bawahan

d. Pengawasan terhadap sikap, tingkah laku dan perbuatan bawahan dilakukan secara ketat

e. Prakarsa harus selalu datang dari pimpinan

f. Tugas-tugas bagi bawahan diberikan secara instruktif

g. Kaku dalam bertindak

2. Gaya kepemimpinan demokratis Kepemimpinan gaya demokratis berciri:

a. Wewenang pimpinan tidak mutlak

b. Pimpinan bersedia melimpahkan sebagian wewenang kepada bawahan 
c. Keputusan dibuat bersama antara pimpinan dan bawahan

d. Komunikasi berlansung timbal balik, baik yang terjadi antara pimpinan dan bawahan maupun sesama bawahan

e. Pengawasan terhadap sikap, tingkah laku, perbuatan atau kegiatan para bawahan dilakukan secara wajar

f. Prakarsa dapat datang dari pimpinan maupun bawahan

g. Pimpinan memperhatikan perasaan dalam bersikap dan bertindak

3. Gaya kepemimpinan laissez faire (kebebasan)

Kepemimpinan gaya kebebasan berciri:
a. Pimpinan melimpahkan wewenang sepenuhnya kepada bawahan

b. Keputusan lebih banyak dibuat bawahan

c. Pimpinan hanya berkomunikasi apabila diperlukan oleh bawahannya

d. Hampir tiada pengawasan terhadap sikap, tingkah laku, perbuatan atau kegiatan yang dilakukan para bawahannya

e. Prakarsa selalu datang dari bawahan

f. Hampir tiada pengarahan dari pimpinan

g. Peranan pimpinan sangat sedikit dalam kegiatan kelompok

\section{METODE PENELITIAN Rancangan Penelitian}

Penelitian ini menggunakan metode penelitian kualitatif, karena tujuannya adalah untuk mendeskripsikan dan menggambarkan apa adanya mengenai suatu variabel, gejala, keadaan atau fenomena sosial tertentu. Pada penelitian ini peneliti ingin melihat bagaimana proses tarbiyah membentuk loyalitas kader PKS di Kota Sungai Penuh.

\section{Populasi dan Objek Penelitian}

Populasi menurut Arikunto (2002:108) adalah keseluruhan obyek penelitian. Populasi dalam penelitian ini adalah keseluruhan kader PKS Kota Sungai Penuh.

\section{Sampel}

Sampel menurut Arikunto (2002:108) adalah wakil dari populasi yang dianggap representatif atau memenuhi syarat untuk menggambarkan keseluruhan dari populasi yang diwakilinya. Sedangkan menurut sugiono (2001:109) adalah sebagian dari jumlah dan karakteristik yang dimiliki oleh populasi tersebut.

Dalam penelitian ini, pengambilan sampel menggunakan purposive sampling yaitu cara penarikan sampel yang dilakukan memilih subjek berdasarkan kriteria spesifik yang ditetapkan oleh peneliti atau penentuan sampel dengan pertimbangan tertentu (Sugiyono, 2008:85). Karena teknik pengambilan sampel tersebut dengan mudah dapat disesuaikan dengan tujuan penelitian. Dalam penelitian ini, peneliti mengambil informan atau narasumber beberapa orang kader PKS yang penulis klasifikasi berdasarkan: pertama, jenjang keanggotaan, meliputi: kader Tamhidi (pemula), Muayyid (muda), Muntasib (Madya), Muntahzim (Dewasa). Kedua, struktur organisasi PKS, meliputi Pengurus DPD (Dewan Pengurus Daerah) PKS Kota Sungai Penuh, Pengurus DPC (Dewan Pimpinan Cabang)/Kecamatan, DPRa (Dewan Pengurus Ranting)/Kelurahan dan kader non-struktural.

\section{Teknik Analisa Data}

Dalam penelitian ini, teknik analisa data yang dipergunakan adalah 
teknik analisa deskriptif, yaitu metode analisa yang dilakukan dengan mengumpulkan, mengolah, menyajikan dan menginterpretasikan data sehingga diperoleh gambaran yang jelas mengenai masalah yang diteliti, kemudian data tersebut diberi komentar sesuai dengan data, fakta dan informasi yang telah dikumpulkan melalui pemahaman intelektual dan pengalaman empiris penulis.

Analisa tabel tunggal merupakan suatu analisa yang dilakukan dengan membagi variabel penelitian kedalam sejumlah frekuensi dan persentase untuk setiap kategori (Singarimbun, 1989 : 267). Dengan langkah-langkah sebagai berikut:

1. Data hasil wawancara dipilih (editing), karena data yang diperoleh dari lapangan sifatnya sangat luas dan tidak semua data tersebut dapat mendukung tujuan penelitian.

2. Data hasil kuesioner dikelompokkan, disusun dan masukkan ke dalam tabel distribusi frekuensi sesuai dengan kategori masing-masing.

\section{HASIL PENELITIAN DAN PEMBAHASAN \\ Proses kaderisasi dalam PKS Landasan ideologis pengkaderan anggota PKS}

Sebagaimana gerakan Islamisme lainnya, landasan ideologis tarbiyah kader PKS adalah Al-Qur'an dan AlHadits. Kegiatan tarbiyah mendasarkan seluruh kegiatannya berdasarkan dua azas tersebut. Gerakan Islamisme, seperti PKS memandang bahwa AlQur'an dan Hadits merupakan panduan hidup utama bagi umat Islam. Menurut mereka, Karena di dalam Al-Qur'an terkandung secara lengkap yang mengatur hidup manusia, mulai dari aspek: ibadah, ilmu pengetahuan, masyarakat, politik, sampai aspek negara atau kepemimpinan, semuanya diatur dan ada panduannya dalam AlQur'an dan Hadits. Mengenai urgensi Al-Qur'an dan Hadits dalam gerakan PKS, sebagaimana dikemukakan oleh Salim Segaf Al-Jufri:

"Sebagai sistem ajaran (value system), Islam tetap menjadi alternatif satu-satunya bagi manusia yang ingin selamat dunia maupun akhirat. Islam juga akan tetap menjadi satu-satunya alternatif peradaban modern umat manusia, pada hari ini dan hari depan. Secara konseptual, Islamlah yang paling layak untuk menggantikan seluruh konsepsi spiritual yang telah ada. Hujjah tekstual tak perlu dipertanyakan lagi. Semuanya bisa lihat dan dikaji dalam kebenarannya dari sumber-sumber pokok ajaran Islam, yaitu al-Qur'an dan as-Sunnah.”

( Salim Segaf Al-Jufri, Menuju Jama'atul muslimin:2001)

Hal senada juga disampaikan oleh Yul Catra Wakil Ketua Umum DPD PKS Kota Sungai Penuh pada penulis pada kesempatan wawancara, dia mengatakan :

"Atas dasar perintah Allah yang disampaikan melalui wahyu kepada Nabi-Nya terutama ayat-ayat yang menekan kewajiban dakwah bagi kaum muslimin, kita disini (Sungai Penuh) ikut membangun PKS untuk tingkat Kota. Dan dengan landasan itulah teman-teman bekerja. Kita berkeyakinan bahwa kebatilan yang terorganisir akan mampu mengalahkan kebenaran yang tidak terorganisir, maka kita sepakat untuk mengorganisir kaderkader dakwah Sungai Penuh ini ke dalam Partai Dakwah (PKS)".

Kemudian dia mengutif beberapa ayat-ayat qur'an dan hadits Rasulullah yang menekankan kewajiban berdakwah bagi kaum muslimin, diantaranya: 
"Dan Aku tidak menciptakan jin dan manusia melainkan supaya mereka menyembah-Ku." (QS. Adz Dzariyat:56).

"Dan hendaklah di antara kamu ada segolongan orang yang menyeru kepada kebajikan, menyuruh (berbuat) yang makruf dan mencegah dari yang mungkar. '(QS. Ali Imran:104).

"Katakanlah (Muhammad), “ inilah jalanku, aku dan orangorang yang mengikuti ku, mengajak kepada Allah dengan yakin, Maha Suci Allah, dan aku tidak termasuk orang-orang yang musyrik”.(QS. Yusuf:108).

"Berangkatlah kamu baik dalam keadaan ringan ataupun berat, dan berjihadlah dengan harta dan dirimu di jalan Allah. Yang demikian itu adalah lebih baik bagi mu jika kamu mengetahui." (QS. At Taubah:41).

"Barangsiapa yang mengajak kepada hidayah (petunjuk dan amal-amal kebaikan), maka ia memperoleh pahala juga pahala dari orang yang mengikutinya, tanpa mengurangi pahala mereka sedikit pun" (Hr. Muslim)

"Barangsiapa yang melihat kemungkaran, maka ubahlah dengan tangannya; jika tidak mampu, maka ubahlah dengan lisannya; dan jika tidak mampu, maka dengan hati, dan ini adalah selemah-lemahnya iman". (Hr. Muslim dan Ahmad)

Ayat-ayat Al-Qur'an dan hadits yang dikutif diatas adalah perintah Allah SWT kepada kaum muslimin untuk berdakwah. Agar islam (kalimah Allah SWT) tetap tegak dimuka bumi dan atas dasar itulah gerakan tarbiyah dan dakwah dijalankan, hal diatas menjadi landasan ideologis bagi kader dakwah.

Yul Catra menambahkan bahwa gerakan Tarbiyah/PKS muncul dari kebijakan politik rezim Orde Baru yang represif khususnya terhadap "Islam politik". Dibubarkannya Masyumi pada awal Orde Baru suatu bukti bahwa secara politik kekuatan islam tidak boleh tampil ke publik yang berpotensi menjadi lawan pemerintah. Lebih jauh diterapkannya azas tunggal Pancasila sebagai landasan dari semua organisasi yang ada, menjadi pemicu sakit hati kalangan Islam terhadap rezim, terutama kalangan Masyumi yang kemudian membentuk DDII.

Sedangkan secara landasan operasional, gerakan tarbiyah banyak mengambil dari pemikiran-pemikiran Hasan Al-Banna yang merupakan pendiri gerakan Ikhwanul Muslimin di Mesir. Adapun beberapa landasan operasional tersebut yang penulis kutip dalam Manhaj Tarbiyah 1433, seperti: Sepuluh Rukun Bai'at oleh Hasan AlBanna, Sepuluh wasiat oleh Hasan AlBanna, Tiga puluh delapan wajibatul akh shadiq oleh Hasan Al-Banna, dan semua yang terdapat dalam buku Risalah Ta'lim (Risalah Pergerakan) yang merupakan kumpulah pidato dan tulisan Hasan Al-Banna.

Otoritarianisme rezim Orde Baru tidak memungkinkan sebuah gerakan, seperti Gerakan Tarbiyah muncul ke publik. Mereka (aktivis dakwah), pada rezim Orde Baru melakukan aktivitasnya secara sembunyi-sembunyi atau underground. Dengan kaderisasi menggunakan sistem halaqoh/liqo, mereka mempunyai keuntungan dibawah rezim yang tertutup tersebut, yaitu menguatnya soliditas organisasi dan terjaganya kemurnian ideologi. Hal ini terjadi karena sistem tarbiyah atau kaderisasi yang mereka lakukan pada saat itu berada pada tahap mihwar tanzimi atau pembentukan organisasi (Rangga Eka Saputra, 2014).

Setelah rezim Soeharto tumbang dan beralih ke era Reformasi, maka ada 
ruang kesempatan politik bagi Gerakan Tarbiyah untuk memperjuangkan dan mengekspresikan idealisme dan cita-cita gerakan mereka ke ruang publik. Ini tercermin dengan dideklarasikannya Partai Keadilan (PK) pada 20 Juli 1998 di Masjid Al-Azhar, Kebayoran Baru, Jakarta, dengan presidennya yang pertama yaitu Nurmahmudi Ismail. Kemudian pada pemilu 1999 PK memperoleh suara nasional sebanyak 1.436.565 atau $1,7 \%$ dan menurut Undang-Undang Nomer 3 tahun 1999 tentang electoral threshold, maka PK dinyatakan tidak memenuhi electoral threshold sebesar $2 \%$ menurut UndangUndang tersebut.

Karena Partai Keadilan tidak lolos electoral threshold pada pemilu 1999, maka pada tanggal 2 Juli 2003 dideklarasikan Partai Keadilan Sejahtera (PKS) yang merupakan transformasi dari Partai Keadilan. Kehadiran PKS mendapat respon baik secara elektoral, hal ini terbukti dari perolehan suara PKS yang naik secara signifikan pada pemilu 2004, yaitu sebanyak 8.325.020 suara nasional atau

7,34 \%, kemudian pada tahun 2009 mendapat 8.204.946 suara atau 7,88\%, dan pada pemilu 2014 mendapat 8.480.204 suara atau 6,79\%.74 Data ini menunjukkan perolehan suara PKS secara elektoral dari tahun 2004 sampai 2014 cenderung stabil.

\section{Tujuan dan proses tarbiyah}

Tujuan tarbiyah adalah pembentukan kader-kader gerakan yang mengamalkan ajaran Islam dalam kehidupan sehari-hari dan bekerja melakukan Islamisasi pada level masyarakat dan negara. Sebagaimana tarbiyah didefinisikan sebagai proses pembentukan seseorang untuk mempunyai kepribadian yang syakhshiyyah Islamiyah (memahami dan menjalankan ajaran/syari'at Islam secara kaffah atau menyeluruh), syakhshiyyah da'iyah (bekerja mendakwahkan Islam), syakhshiyyah Ijtima'iyah (berinteraksi dan berkiprah positif dalam masyarakat), dan syakhshiyyah Dauliyah (mampu berperan dalam mengurus negara). Jadi, fokus yang diperhatikan dalam proses tarbiyah adalah terbentunya individuindividu gerakan yang Islami dan mampu meng-Islamiasasi masyarakat dan negara.

Berangkat dari penjelasan Greg Fealy yang mengungkapkan bahwa PKS mempunyai dua agenda atau tujuan dalam aktifitas gerakannya. Pertama agenda elektoral yang difokuskan pada kinerja pelayanan sosial, wacana anti korupsi, dan wacana penciptaan good governance. Di sisi lain dalam trainingtraining (proses tarbiyah) yang mereka lakukan, terlihat bahwa PKS mempunyai agenda internal (private agenda) yang menekankan pada pemurnian ajaran Islam, disiplin internal, dan penerapan syariah.

Menurut gerakan PKS tidak ada dikotomi antara agama dan politik (negara) dalam Islam. Menurut mereka Islam adalah agama yang universal dan integral, yang mencakup seluruh aspek kehidupan, mulai dari aspek akidah, ibadah, politik, hukum, pendidikan, jihad, militer, dan pemikiran (Cahyadi,2003:85). Ini merupakan manfestasi dari ideologi Islamisme yang memandang bahwa Islam adalah agama yang Kaffah dan mencakup seluruh bidang kehidupan manusia.

Secara eksplisit kader PKS tidak membantah kalau tujuan dari gerakan mereka adalah untuk menerapakan nilai atau syariah Islam. Menurut mereka dakwah secara umum adalah proses mengaplikasikan nilai-nilai Islam dalam kehidupan sehari-hari manusia di segala bidang (Cahyadi,2003:1). Mereka menganggap bahwa proses tarbiyah merupakan proses yang dilakukan para 
nabi dan rasul, sehingga aktivitas yang dilakukan dalam proses dakwah ini adalah proses yang mulia (Cahyadi,2003:1).

Penulis melakukan wawancara dengan Emprizal Ketua DPD PKS Kota Sungai Penuh berkaitan dengan tujuan dan agenda ideologis PKS tersebut. Penulis bertanya mengenai strategi dakwah PKS yang disebut empat mihwar (orbit) dakwah. Mihwar tersebut meliputi: tanzhimi (pembentukan organisasi), sya'bi (berinteraksi dengan masyarakat), muassasi (masuk dalam institusiinstitusi politik), daulah (pendirian negara/regional), ustazatul alam (soko guru dunia). Menyangkut hal ini terutama pada mihwar daulah, Emprizal menjelaskan "bahwa yang dimaksud adalah agar masyarakat Indonesia menerapkan nilai-nilai Islam dalam kehidupan sehari-hari". Usaha PKS, lanjut Em, seperti "mendukung perda-perda syariah atau undangundang yang "berbau" nilai Islam, seperti UU Pornografi \& Pornoaksi yang PKS perjuangkan di parlemen". Dari jawaban Emprizal tersebut, jelas bahwa PKS mempunyai agenda internal untuk penerapan syariah Islam atau melakukan Islamisasi di Indonesia.

Tarbiyah merupakan proses yang terencana dalam gerakan Tarbiyah/PKS, dalam konteks menguatkan disiplin dan kapasitas kader. Proses tarbiyah mempunyai beberapa sarana, antara lain: halaqoh/usrah/liqo, mabit (malam bina iman dan taqwa), tasqif (tarbiyah tsaqofiyah) atau pendidikan untuk memperluas wawasan ke-Islaman kader, daurah (pelatihan), ta"lim, rihlah (liburan), mukhayyam (berkemah), dan lain-lain. Sarana-sarana tersebut merupakan suatu hal yang wajib diikuti oleh para kader-kader PKS. Melalui proses terbiyah ini, proses kaderisasi dan pembentukan kader yang loyal terhadap gerakan berlangsung.

Sarana tarbiyah yang terpenting bagi gerakan PKS dalam pengkaderan adalah halaqoh/liqo. Halaqoh/liqo merupakan sebuah aktifitas inti dari gerakan PKS, dan menjadi pembatas antara anggota gerakan dan bukan anggota gerakan. Melalui keterlibatannya dalam halaqoh/liqo seseorang dikatakan sebagai bagian dari gerakan. Sehingga, proses halaqoh merupakan kewajiban bagi setiap anggota gerakan Tarbiyah/PKS. Halaqoh/liqo rutin dilakukan setiap sepekan sekali oleh seluruh kader gerakan. Di dalam halaqoh/liqo, anggota gerakan mengkaji ajaran Islam yang telah disusun kurikulumnya oleh struktur PKS. Selain mengkaji Islam, halaqoh/liqo juga sebagai sarana PKS untuk memberikan intruksi atau penjelasan yang berkaitan dengan politik atau gerakan. Anggota dalam setiap kelompok halaqoh/liqo biasanya antara delapan sampai dua belas orang.

Dalam halaqoh/liqo, terdapat seorang guru atau ustad yang disebut murabbi. Murabbi merupakan orang yang menjadi guru dalam halaqoh/liqo, baik menyampaikan materi atau melanjutkan memberikan instruksi atau penjelasan dari struktur PKS. Dalam budaya gerakan Tarbiyah/PKS terdapat penghormatan yang luar biasa terhadap guru atau murabbi. Sebagaimana dijelaskan bahwa hak murabbi/naqib: didengar dan ditaati, diminta pendapat, dihargai dan dihormati, mengajukan permintaan bantuan untuk melaksanakan tugas, memutuskan kebijakan, membentuk kepengurusan halaqoh, mendapat pelatihan-pelatihan, dan mengajukan peserta tarbiyahnya untuk dinaikkkan ke jenjang tarbiyah yang lebih tinggi. 
Pengaruh Pola Kaderisasi terhadap Loyalitas Kader pada PKS

Pengaruh Rukun Bai'at dalam gerakan PKS

Rukun bai'at merupakan suatu hal yang wajib dipahami dan diimplemtasikan bagi para anggota kader PKS. Rukun bai'at disebut juga janji setia anggota kepada gerakan Tarbiyah/PKS. Rukun ini sebenarnya dibuat oleh Hasan Al-Banna sebagai janji setia setiap anggota gerakan Ikhwanul Muslimin. Ada sepuluh rukun baiat: fahm (pemahaman), ikhlas, amal, jihad, tadhiyyah (pengorbanan), taat (ketaatan), tsabat (keteguhan), tajarrud (kemurnian), ukhwah (persaudaraan), dan tsiqoh (kepercayaan).

Untuk mengetahui bagaimana pemahaman kader tentang bai'at dan apakah bai'at memberi pengaruh dalam pembentukan loyalitas kader PKS di Kota Sungai Penuh, penulis mengajukan pertanyaan sebagai berikut:

a. Apakah di bai'at waktu masuk menjadi anggota PKS;

b. Apakah anda memahami apa itu bai'at; dan

c. Apakah bai'at berpengaruh terhadap loyalitas anda kepada partai

Tabel 1

Jawaban Responden Berdasarkan Pertanyaan

Apakah di bai'at waktu masuk menjadi anggota $P K S$

\begin{tabular}{|c|c|c|c|}
\hline No & Jawaban & Jumlah & Persentase \\
\hline 1. & $\mathrm{Ya}$ & 31 & 67,40 \\
\hline 2. & Tidak & 15 & 32,60 \\
\hline & Total & 46 & 100,00 \\
\hline
\end{tabular}

Merujuk kepada tabel dapat kita ketahui bahwa mayoritas responden mengaku bahwa mereka di bai'at waktu masuk menjadi anggota PKS. Hal ini dapat dilihat dari banyaknya frekuensi responden yang menyatakan bahwa mereka di bai'at ketika masuk PKS yaitu 31 orang $(67,40 \%)$, sedangkan yang menyatakan tidak sebanyak 15 orang $(32,60 \%)$.

Tabel 2

Jawaban Responden

Berdasarkan Pertanyaan

Apakah anda memahami apa itu bai'at

\begin{tabular}{|c|c|c|c|}
\hline $\begin{array}{c}\text { No } \\
\text {. }\end{array}$ & Jawaban & Jumlah & Persentase \\
\hline 1. & Ya & 40 & 86,96 \\
2. & Tidak & 6 & 13,04 \\
\hline \multicolumn{2}{r|}{ Total } & $\mathbf{4 6}$ & $\mathbf{1 0 0 , 0 0}$ \\
\hline
\end{tabular}

Berdasarkan tabel tersebut dapat dilihat bahwa mayoritas responden menjawab bahwa mereka memahami apa itu bai'at yakni sebanyak 40 responden $(86,96 \%)$. Sedangkan yang kurang memahami atau tidak memahami sebanyak 6 responden $(13,04)$.

Tabel 3

Jawaban Responden

Berdasarkan Pertanyaan

Apakah bai'at berpengaruh

terhadap loyalitas anda kepada partai

\begin{tabular}{|c|c|c|c|}
\hline No & Jawaban & Jumlah & Persentase \\
\hline 1. & $\mathrm{Ya}$ & 41 & 89,13 \\
\hline 2. & Tidak & 5 & 10,87 \\
\hline & Total & 46 & 100,00 \\
\hline
\end{tabular}


menjawab bahwa dengan adanya bai'at mereka merasa sangat terikat dengan partai dan sangat berpengaruh terhadap loyalitas kader terhadap partainya dan selebinya sebanyak 5 responden $(10,87)$ menyatakan tidak. Berarti jika dilihat secara keseluruhan dari responden kebanyakan mereka menyatakan memahami apa itu bai'at dan mengakui bai'at sangat berpengaruh terhadap loyalitas kader pada partai.

Sebagai manifestasi dari pemahaman Islam yang kaffah, rukun baiat merupakan syarat utama bagi kader dalam gerakan Tarbiyah/PKS. Lebih jauh, rukun bai' at menurut Hasan Al-Banna merupakan sebuah keniscayaan dan harus dipenuhi oleh setiap kader gerakan agar dapat menunaikan tugasnya dalam jamaah (gerakan), dan tidak terpenuhinya salah satu rukun ini akan membuat seorang kader menjadi cacat, dan selanjutnya cacat pula gerakan oleh kader tersebut.

Rukun bai'at menjadi keharusan bagi gerakan PKS untuk disampaikan kepada kadernya. Rukun baiat disampaikan pada saat pelantikan Pengurus DPC, DPRa dan halaqoh/liqo. Secara khusus ada penugasan dari murabbi kepada binaannya untuk membaca dan menghapal rukun baiat ini. Menurut Said Hawwa, tanggung jawab pertama gerakan adalah mewujudkan rukun-rukun bai'at yang sepuluh kepada setiap individu, sebagai jalan untuk membangun gerakan Islam yang komprehensif (kaffah). Misalnya kader gerakan PKS sangat ditekankan untuk tsiqoh (percaya) dan taat (patuh) kepada pemimpin dan murabbi meraka. Percaya dan patuh kepada murabbi merupakan rukun bai'at yang wajib dilaksanakan oleh setiap anggota gerakan.

\section{Pengaruh Liqo pada kesetiaan kader}

Sarana tarbiyah yang terpenting bagi gerakan PKS dalam pengkaderan adalah halaqoh/liqo. Halaqoh/liqo merupakan sebuah aktifitas inti dari gerakan PKS, dan menjadi pembatas antara anggota gerakan dan bukan anggota gerakan. Melalui keterlibatannya dalam halaqoh/liqo seseorang dikatakan sebagai bagian dari gerakan. Sehingga, proses halaqoh merupakan kewajiban bagi setiap anggota gerakan Tarbiyah/PKS.

Halaqoh/liqo rutin dilakukan setiap sepekan sekali oleh seluruh kader gerakan. Di dalam halaqoh/liqo, anggota gerakan mengkaji ajaran Islam yang telah disusun kurikulumnya oleh struktur PKS. Selain mengkaji Islam, halaqoh/liqo juga sebagai sarana PKS untuk memberikan intruksi atau penjelasan yang berkaitan dengan politik atau gerakan. Anggota dalam setiap kelompok halaqoh/liqo biasanya antara delapan sampai dua belas orang.

Dalam halaqoh/liqo, terdapat seorang guru atau ustad yang disebut murabbi. Murabbi merupakan orang yang menjadi guru dalam halaqoh/liqo, baik menyampaikan materi atau melanjutkan memberikan instruksi atau penjelasan dari struktur PKS. Dalam budaya gerakan Tarbiyah/PKS terdapat penghormatan yang luar biasa terhadap guru atau murabbi (Arief Munandar,2004:212). Sebagaimana dijelaskan bahwa hak murabbi/naqib didengar dan ditaati, diminta pendapat, dihargai dan dihormati, mengajukan permintaan bantuan untuk melaksanakan tugas, memutuskan kebijakan, membentuk kepengurusan halaqoh, mendapat pelatihan-pelatihan, dan mengajukan peserta tarbiyahnya untuk dinaikkkan ke jenjang tarbiyah yang lebih tinggi. 
Tabel 4

Jawaban Responden Berdasarkan Pertanyaan

Apakah Halaqo/Liqo adalah bentuk tarbiyah dalam PKS

\begin{tabular}{|c|c|c|c|}
\hline $\begin{array}{c}\text { No } \\
\text {. }\end{array}$ & Jawaban & Jumlah & Persentase \\
\hline 1. & Ya & 46 & 100,00 \\
& & & \\
2. & Tidak & 0 & 0 \\
& & & \\
\hline & Total & $\mathbf{4 6}$ & $\mathbf{1 0 0 , 0 0}$ \\
\hline
\end{tabular}

Berdasarkan tabel diatas dapat dilihat bahwa semua responden $(100,00 \%)$ menjawab bahwa Halaqo/Liqo adalah bentuk tarbiyah dalam PKS.

Tabel 5

Jawaban Responden Berdasarkan Pertanyaan

Apakah Halaqo/Liqo

menambah Pengetahuan Agama

\begin{tabular}{|c|c|c|c|}
\hline $\begin{array}{c}\text { No } \\
\text { 1. }\end{array}$ & Jawaban & Jumlah & Persentase \\
\hline 1. & Ya & 46 & 100,00 \\
2. & Tidak & 0 & 0 \\
& & & \\
\hline & Total & $\mathbf{4 6}$ & $\mathbf{1 0 0 , 0 0}$ \\
\hline
\end{tabular}

Tabel menunjukkan kepada kita bahwa secara keseluruhan responden mengatakan bahwa halaqo/liqo menambah pengetahuan ilmu agama bagi mereka.
Tabel 6

Jawaban Responden Berdasarkan Pertanyaan

Apakah Halaqo/Liqo memberikan konstribusi terhadap Loyalitas anda pada Partai

\begin{tabular}{|c|c|c|c|}
\hline $\begin{array}{c}\text { No } \\
\text {. }\end{array}$ & Jawaban & Jumlah & Persentase \\
\hline 1. & Ya & 40 & 86,96 \\
2. & Tidak & 6 & 13,04 \\
& & & \\
\hline \multicolumn{2}{|c|}{ Total } & $\mathbf{4 6}$ & $\mathbf{1 0 0 , 0 0}$ \\
\hline
\end{tabular}

Dari tabel dapat kita ketahui bahwa mayoritas responden $(86,96 \%)$ mengatakan bahwa halaqo/liqo memberikan pengaruh yang besar terhadap pembentukan loyalitas kader pada partai. Hal ini dikarenakan kegiatan kumpul bersama seperti ini otomatis akan menguatkan tali silatuhrahmi sesama kader PKS. Dari penguatan silatuhrami ini akan menghasilkan kader-kader yang solid dan setia atau loyal pada partai.

Sedangkan 6 orang responden $(13,04)$ menyatakan tidak.

Pengaruh kepemimpinan PKS terhadap Loyalitas Kader

"Sesungguhnya bagi kaum saba ada tanda (kekuasaan Tuhan) di tempat kediaman mereka yaitu dua buah kebun di sebelah kanan dan sebelah kiri. (kepada mereka dikatakan), "makanlah oleh mu dari rezeki yang (dianugerahkan) Tuhan mu dan bersyukurlah kepada-Nya. (negeri mu) adalah negeri yang baik dan (Tuhan mu) adalah Tuhan Yang Maha Pengampun. Tetapi mereka berpaling, maka kami datangkan kepada mereka banjir yang besar dan kami 
ganti kedua kebun mereka dengan dua kebun yang ditumbuhi (pohon-pohon) yang berbuah pahit,..."

(QS. Saba:15-16).

Dalam surah saba tersebut Allah Azza wajalla mengabarkan bahwa zaman dahulu ada negeri yang subur, hijau, indah dan mendatangkan kemakmuran bagi penduduknya (kaum saba). Suatu negeri yang berada di Syam. Namun, para pemimpin dan masyarakatnya tidak bersyukur atas nikmat Tuhannya, bahkan berpaling, ujung-ujungnya negeri saba menjadi negeri yang berantakan.

Kader-kader PKS sungguh amat khawatir kasus seperti disebutkan dalam surah saba diatas menimpa bangsa dan negara ini, disebabkan tidak dikelola sesuai syariat Allah SWT. Partai islam mempunyai ketegasan ingin Indonesia menjadi negara maju, yang jaya, yang hebat dengan metode dikelola sesuai dengan syariat yang diajarkan oleh Allah SWT. Negeri yang subur, makmur, aman dan dalam ridho Ilahi, pemerintahannya harus dipimpin orang yang beriman dan bertaqwa. Hal ini sesuai dengan firman Allah Azza wajalla :

"Sesungguhnya penolong mu (pemimpin mu) hanyalah Allah, Rasul-Nya dan orang-orang yanng beriman, yang melaksanakan salat dan menunaikan zakat, seraya tundauk (kepada Allah). (QS.AlMaidah: 55).

Kader-kader PKS meyakini sumber kepemimpinan nasional yang islami ada dalam partai islam. Bahkan dalam ayat 57 surah al-maidah ditegaskan, jangan sekali-kali mengambil jadi pemimpin orang yang melecehkan dan merendahkan agama islam. Inilah faktor yang membuat kader-kader PKS tetap loyal pada partainya.

Tabel 7

Jawaban Responden Berdasarkan Pertanyaan Apakah pemimpin PKS memberikan teladan yang baik

\begin{tabular}{|c|c|c|c|}
\hline $\begin{array}{c}\text { No } \\
.\end{array}$ & Jawaban & Jumlah & Persentase \\
\hline 1. & Ya & 27 & 58,70 \\
2. & Tidak & 19 & 41,30 \\
& & & \\
\hline \multicolumn{2}{|c|}{ Total } & $\mathbf{4 6}$ & $\mathbf{1 0 0 , 0 0}$ \\
\hline
\end{tabular}

Berdasarkan tabel di atas dapat diketahui bahwa mayoritas responden menjawab bahwa para pemimpin PKS memberikan teladan yang baik bagi anggotanya yakni sebanyak 27 orang responden $(58,70 \%)$. Sedangkan sisanya menjawab sebaliknya sebanyak 19 orang responden $(41,30 \%)$.

Tabel 8

Jawaban Responden Berdasarkan Pertanyaan Apakah gaya kepemimpinan PKS membuat anda loyal Kepada partai

\begin{tabular}{|c|c|c|c|}
\hline No & Jawaban & Jumlah & Persentase \\
\hline 1. & $\mathrm{Ya}$ & 25 & 54,35 \\
\hline 2. & Tidak & 21 & 45,65 \\
\hline & Total & 46 & 100,00 \\
\hline
\end{tabular}
sebanyak 25 orang responden $(54,35 \%)$ menjawab bahwa gaya kepemimpinan PKS turut membentuk loyalitas mereka 
kepada partai. Sedangkan 21 orang responden $(45,65 \%)$ menyatakan tidak.

Tabel 9

Jawaban Responden Berdasarkan

Pertanyaan Apakah gaya

kepemimpinan PKS mempengaruhi perolehan suara PKS pada

pemilu 2004

\begin{tabular}{|c|c|c|c|}
\hline $\begin{array}{c}\text { No } \\
.\end{array}$ & Jawaban & Jumlah & Persentase \\
\hline 1. & Ya & 24 & 52,17 \\
& & & \\
2. & Tidak & 22 & 47,83 \\
& & & \\
\hline \multicolumn{2}{r|}{ Total } & $\mathbf{4 6}$ & $\mathbf{1 0 0 , 0 0}$ \\
\hline
\end{tabular}

Dari tabel dapat kita ketahui

bahwa banyak responden menjawab bahwa gaya kepemimpinan PKS menpengaruhi perolehan suara PKS pada pemilu 2014 yakni sebanyak 24 orang responden $(52,17 \%)$, sedangkan responden yang menjawab sebaliknya sebanyak 22 orang responden $(47,83)$.

\section{PENUTUP}

\section{Kesimpulan}

Berdasarkan pembahasan yang telah dilakukan pada bab sebelumnya, maka dapat ditarik sebuah kesimpulan berikut ini:

a. Landasan ideologis pembinaan kader PKS bersumber dari Alqur'an dan hadits. PKS memandang bahwa Al-qur'an dan hadits merupakan panduan hidup utama bagi umat islam. Di dalam Alqur'an terkandung secara lengkap yang mengatur hidup manusia, mulai dari aspek: ibadah, ilmu pengetahuan, masyarakat, politik, sampai aspek negara atau kepemimpinan negara.

b. Tujuan pembinann adalah pembentukan kader-kader gerakan yang mengamalkan ajaran islam dalam kehidupan sehari-hari dan bekerja melakukan islamisasi pada level masyarakat dan negara. Tarbiyah didefinisikan sebagai proses pembentukan seseorang agar mempunyai kepribadian yang syakhshiyyah Islamiyah (memahami dan menjalankan ajaran/syari'at Islam secara kaffah atau menyeluruh), syakhshiyyah da'iyah (bekerja mendakwahkan Islam), syakhshiyyah Ijtima'iyah (berinteraksi dan berkiprah positif dalam masyarakat), dan syakhshiyyah Dauliyah (mampu berperan dalam mengurus negara)

c. Sarana pembinaan yang terpenting bagi gerakan PKS dalam pengkaderan adalah halaqoh/liqo. Halaqoh/liqo merupakan sebuah aktifitas inti dari gerakan PKS, dan menjadi pembatas antara anggota gerakan dan bukan anggota gerakan. Di dalam halaqoh/liqo, anggota gerakan mengkaji ajaran Islam yang telah disusun kurikulumnya oleh struktur PKS. Selain mengkaji Islam, halaqoh/liqo juga sebagai sarana PKS untuk memberikan intruksi atau penjelasan yang berkaitan dengan politik atau gerakan. Anggota dalam setiap kelompok halaqoh/liqo biasanya antara delapan sampai dua belas orang. Dengan melakukan bersama seperti ini otomatis akan menguatkan tali silahturahmi sesama kader PKS. Dari penguatan silahturahmi ini akan menghasilkan kader-kader yang solid serta setia.

d. Bai'at merupakan suatu janji setia anggota kepada gerakan tarbiyah/PKS. Rukun bai'at terdiri dari: fahm (pemahaman), ikhlas, amal, jihad, tadhiyyah (pengorbanan), taat (ketaatan), tsiqoh (kepercayaan).

e. Dari hasil kuisioner tentang bai'at 
dapat kita ketahui bahwa mayoritas responden $(89,13 \%)$ menyatakan bahwa mereka sangat terikat dengan partai setelah di bai'at dan sangat besar pengaruhnya terhadap loyalitas kader. Kemudian hasil dari kuisioner tentang halaqo/liqo dapat kita lihat bahwa sebesar $86,96 \%$ responden juga menyatakan halaqo/liqo memberikan konstribusi terhadap pembentukan loyalitas kader. Sedangkan hasil dari kuisioner tentang gaya kepemimpinan PKS di dapat hasilnya sebesar 54,35\% responden menjawab bahwa gaya kepemimpinan PKS turut membentuk loyalitas mereka pada partai.

\section{Saran}

1. Penelitian ini masih dilakukan dalam wilayah kajian yang masih sempit yaitu hanya di Kota Sungai Penuh dengan sampel responden sebanyak 46 orang. Oleh karena itu perlu ada penelitian lanjutan dengan wilayah kajian yang lebih luas sehingga hasil penelitiannya benar-benar dapat menghasilkan informasi akurat yang dapat menjelaskan tentang proses dan dampak tarbiyah terhadap eksistensi parpol islam di Indonesia.

2. Peranan tarbiyah sangat besar dalam pembentukan kader-kader yang berkualitas dan militan untuk menjaga eksistensi partai dalam kancah politik nasional atau di tingkat lokal maka, perlu peningkatan kapasitas pengurus partai yang membidangi kaderisasi.

3. Agar parpol islam bisa menjadi partai modern dan aspiratif maka perlu meluaskan materi tarbiyah dari hanya aspek keagamaan juga aspek pengetahuan administrasi, manajemen, kebijakan publik dan lain sebagainya.

\section{Implikasi Peneltian}

Berdasarkan hasil penelitian, maka dirumuskan implikasi hasil penelitian sebagai berikut :

1. Teori-teori tentang kaderisasi partai, pengelolaan tarbiyah dan loyalitas kader akan banyak di pelajari khususnya oleh pihak yang mengelola partai politik sebagai bekal agar dapat memahami dengan baik tentang pengelolaan kader Partai agar berkualitas dan loyal. Dengan demikian, teori-teori tersebut akan lebih menjadi berkembang dan dinamis karena akan banyak dicari dan di butuhkan oleh praktisi politik.

2. Agar hasil kaderisasi/tarbiyah kedepannya dapat memiliki kategori baik maka ada beberapa hal yang bisa lakukan oleh para pengurus partai diantaranya : membangun training center yang dikelaola dengan baik. Lembaga ini yang digunakan sebagai sarana peningkatan kapasitas para murabbi atau ketua bidang kaderisasi partai agar lebih kompeten dalam menjalankan tupoksinya.

\section{DAFTAR PUSTAKA}

Abdullah, Rahmat. 2004. Untuk mu Kader Dakwah. Jakarta. Pustaka Dakwatuna.

$\begin{array}{rrr}\text { Marzuki Ali, 2010. } & \text { Pemasaran } \\ \text { Politik } & \text { dan } & \text { Politik } \\ \text { Kepartaian di } & \text { Indonesia } \\ \text { (kajian } & \text { Pemilihan } & \text { Umum } \\ \text { Tahun } 2009 \text { di } & \text { Daerah }\end{array}$


Khusus Ibukota Jakarta)

Disertasi Doktor UUM

Malaysia

Al-Banna, Hasan. 2005. Risalah

Pergerakan Ikhwanul

Muslimin. Solo: Era

Intermedia.

Ali-Jabir, Hussaian bin Muhamad. 2001. Menuju Jama'atul Muslimin: Telaah Sistem Jamaah dala Gerakan Islam. Jakarta. Rabbani Press.

Aminuddin, KH. Hilmi. 2008. Menghilangkan trauma persepsi. Jakarta. ARAH Press.

Hawwa, Sa'id. 2000. Membina Angkatan Mujahid: Studi Analisis atas Konsep Dakwah Hasan Al-Banna dalam Risalah Ta'lim. Solo: Era Intermedia.

Hawwa, Sa'id dan Sayyid Quthb. 2001.Al-wala: Loyalitas Tunggal Seorang Muslim. Jakarta: Al-I'tishom Cahaya Umat.

Sargent,L.T 1987. Contemporary Political Ideologies, A Comparative Analysis. Pasific Grove, California: Brooks/Cole Publishing Company

Marlius, D. RD Putra. (2018). Strategi Pengembangan Sulam Bayang. Jurnal Benefita: Ekonomi Pembangunan Manajemen Bisnis Dan Akuntansi. Volume 3. No. 2. Hal. 204-218. http://doi.org/10.22216/jbe.v3i2. 3494

Muhtadi, Burhanudin. 2012. Dilema PKS: Suara dan Syari'ah, Jakarta. Kepustakaan Populer Gramedia.

Fiorina, M.P. 1981. The Voting Decision : Instrumental and Experience Aspect, Journal Of Politics, 38,390-415

Joseph La Palombara (1987) "Political Parties and Political Development Princeton, NJ: Princeton University Press,

Prayitno, Irwan. 2003. Kepribadian Dai. Bekasi. Pustaka Tarbiyatuna.

Bone, H.A dan A. Ranney. 1976. Politics and Voters, New York : McGraw-Hill,Inc.

Takariawan, Cahyadi. 2003. Rekayasa Masa Depan Menuju Kemenangan Dakwah Islam. Jakarta. Pustaka Tarbiatuna.

Meldi, M. Heryanto, H. (2019). The Influence Of Quality Of Human Resources And Communication On The Performance Of Civil Servants In The Regional Secretariat Of Dharmasraya Regency With Organizational Commitment As Intervening Variables. Archives of Business Research 7 (7), 132141

Wahyuni, N. Heryanto, H. (2019). The Effect of Environment and Motivation on Employee Performance with 
Organizational Culture as an intervening variable on Bank Perkreditan Rakyat Jorong Kampung Tangah Pariaman PT. Archives of Business Research 7 (5)

Moleong, Lexy J. 1993. Metode Penelitian Kualitatif. Bandung: PT. Remaja Rosdakarya.

Edasa, D. Putra, EE. (2015). Pengaruh Gaya Kepemimpinan, Lingkungan Kerja dan Motivasi Kerja Terhadap Kinerja Pegawai LPP-RRI Bukittinggi. Jurnal Riset Manajemen Bisnis dan Publik 3 (2)

Eka Saputra, Rangga. 2014. Dinamika Internal PKS Dalam Merespon Kasus Korupsi Luthfi Hasan Ishaaq Menjelang Pemilu 2014. Skripsi, UIN Syrif Hidayatullah.

Fuholin, Elisa. 2001. Image of Subtance? Candidate of Campaign ? A Case Study of a Presidential Election Campaign in Finland, Corporate Communications: An International Journal, 6(3):124-130

Yusrisal, Y. Heryanto, H.( 2019). The Influence of Leadership and Competence on Work Motivation and its impact on Employee Performance at the Koto Besar Sub-District Office, Dharmasraya Regency. Archives of Business Research 7 (7), 122131
Syukri, M. Heryanto, H. (2019). The Influence Of Leadership Style, And Organizational Commitment, On Employee Discipline And Also Its Impact On Employee Performance Of The Dharmasraya District Community And Village Empowerment Office. Archives of Business Research 7 (7), 102111

Ajzen, I. 1991, The Theory of Planned Behaviour, Organization Behaviour and Human Decision Processes.50,179-211.

Maryanti, S. Eliza, Y. Wiyati, R. Thamrin, M. (2018). The Growth of the Population: Labor Potential Mapping in Pekanbaru Indonesia. IOP Conference Series: Earth and Environmental Science 175 (1), 012092

Maryanti, S. Eliza, Y. Wiyati, R.

Thamrin, M. (2018). The

Growth of the Population: Labor Potential Mapping in Pekanbaru Indonesia. IOP Conference Series: Earth and Environmental Science 175 (1), 012092

Eliza, Y. (2015). Analisis Kepuasan

Masyarakat Atas Kualitas Pelayanan Kantor Kecamatan Siberut Selatan Kabupaten Kepulauan Mentawai. Jurnal Pendidikan Ekonomi dan Bisnis 7 (1), 65-75

Yuharmain, H. Suryana, Y. Novianty, R, Joeliaty. (2016). An Impact Study Of Rural Credit Bank Existence Towards Micro And Small Businesses In Padang 
City. International Journal Of

Scientific \& Technology

Research 5 (7), 145-150

Putra, EE. (2015). Keadilan Dalam

Organisasi. Buletin Organisasi dan Aparatur

Putra, EE. (2015). Pentingnya ISO Bagi

Lembaga Pendidikan Dan

Latihan. Buletin Badan Diklat

Prov. Sumatera Barat

Putra, EE. (2015). Urgensi

Pengembangan Potensi Aparatur

Sipil Negara (ASN). Buletin

Badan Diklat Prov. Sumatera

Barat

Putra, EE. (2014). The Effect of Human

Capital, Structural and Customer

Capital to Performance of Small

Medium Enterprises at West

Sumatera Province. Business

Administration at Jose Rizal

University

Putra, RY. Marlius, D. (2019).

Pengaruh

Pendidikan,

Pengalaman Kerja dan Etos

Kerja Terhadap Kinerja Pegawai

Di KPN Batur. Academic

Conference For Management 2.

Bungin, B. 2010, Metodologi

Penelitian Kualitatif:

Aktualisasi Metodologis ke

Arah Ragam Varian

Kontemporer,Jakarta: PT Raja

Grafindo Persada.

Sekaran, U. 2003. Research Methods for Business: A Skill Building Approach. USA:

John Wiley \& Soons,Inc 